\title{
Did Wages Reflect Growth in Productivity?
}

\section{Citation}

Feldstein, Martin. 2008. Did wages reflect growth in productivity? Journal of policy modeling 30(4): 591-594.

\section{Published Version}

http://dx.doi.org/10.1016/j.jpolmod.2008.04.003

\section{Permanent link}

http://nrs.harvard.edu/urn-3:HUL.InstRepos:2794832

\section{Terms of Use}

This article was downloaded from Harvard University's DASH repository, and is made available under the terms and conditions applicable to Open Access Policy Articles, as set forth at http:// nrs.harvard.edu/urn-3:HUL.InstRepos:dash.current.terms-of-use\#OAP

\section{Share Your Story}

The Harvard community has made this article openly available.

Please share how this access benefits you. Submit a story.

Accessibility 
NBER WORKING PAPER SERIES

DID WAGES REFLECT GROWTH IN PRODUCTIVITY?

\author{
Martin S. Feldstein \\ Working Paper 13953 \\ http://www.nber.org/papers/w13953 \\ NATIONAL BUREAU OF ECONOMIC RESEARCH \\ 1050 Massachusetts Avenue \\ Cambridge, MA 02138 \\ April 2008
}

This paper was presented at the American Economic Association meetings, January 2008, and will be published in the Journal of Policy Modeling, 2008. The views expressed herein are those of the author(s) and do not necessarily reflect the views of the National Bureau of Economic Research.

(C) 2008 by Martin S. Feldstein. All rights reserved. Short sections of text, not to exceed two paragraphs, may be quoted without explicit permission provided that full credit, including $\odot$ notice, is given to the source. 
Did Wages Reflect Growth in Productivity?

Martin S. Feldstein

NBER Working Paper No. 13953

April 2008

JEL No. E24,J3

\begin{abstract}
$\underline{\text { ABSTRACT }}$
The level of productivity doubled in the U.S. nonfarm business sector between 1970 and 2006. Wages, or more accurately total compensation per hour, increased at approximately the same annual rate during that period if nominal compensation is adjusted for inflation in the same way as the nominal output measure that is used to calculate productivity.

Total employee compensation as a share of national income was 66 percent of national income in 1970 and 64 percent in 2006. This measure of the labor compensation share has been remarkably stable since the 1970s. It rose from an average of 62 percent in the decade of the 1960s to 66 percent in the decades of the 1970s and 1980s and then declined to 65 percent in the decade of the 1990s where it has again been from 2000 until the most recent quarter.
\end{abstract}

\author{
Martin S. Feldstein \\ President and Chief Executive Officer \\ NBER \\ 1050 Massachusetts Avenue \\ Cambridge, MA 02138-5398 \\ and NBER \\ msfeldst@nber.org
}




\section{Did Wages Reflect Growth in Productivity?}

\section{Martin Feldstein ${ }^{*}$}

The level of productivity doubled in the U.S. nonfarm business sector between 1970 and 2006. Wages, or more accurately total compensation per hour, increased at approximately the same annual rate during that period if nominal compensation is adjusted for inflation in the same way as the nominal output measure that is used to calculate productivity.

More specifically, the doubling of productivity since 1970 represented a 1.9 percent annual rate of increase. Real compensation per hour rose at 1.7 percent per year when nominal compensation is deflated using the same nonfarm business sector output price index.

In the more recent period between 2000 and 2007, productivity rose much more rapidly (2.9 percent a year) and compensation per hour rose nearly as fast (2.5 percent a year).

The relation between productivity and wages has been a source of substantial controversy, not only because of its inherent importance but also because of the conceptual measurement issues that arise in making the comparison.

\footnotetext{
*Professor of Economics, Harvard University, and President and CEO of the National Bureau of Economic Research. This paper was presented at the annual meeting of the American Economic Association on January 5, 2008. I am grateful to Mark Shepard for research assistance. 
The relation between wages and productivity is important because it is a key determinant of the standard of living of the employed population as well as of the distribution of income between labor and capital. If wages rise at the same pace as productivity, labor's share of national income remains essentially unchanged. This paper presents specific evidence that this has happened: the share of national income going to employees is at approximately the same level now as it was in 1970.

Two principal measurement mistakes have led some analysts to conclude that the rise in labor income has not kept up with the growth in productivity. The first of these is a focus on wages rather than total compensation. Because of the rise in fringe benefits and other noncash payments, wages have not risen as rapidly as total compensation. It is important therefore to compare the productivity rise with the increase of total compensation rather than with the increase of the narrower measure of just wages and salaries.

The second measurement problem is the way in which nominal output and nominal compensation are converted to real values before making the comparison. Although any consistent deflation of the two series of nominal values will show similar movements of productivity and compensation, it is misleading in this context to use two different deflators, one for measuring productivity and the other for measuring real compensation.

A quick review of what economic theory says about the relation between productivity and compensation will clarify the correct choice of price deflator for 
making this comparison and will also indicate how productivity and compensation would be expected to move in a competitive economy. In the classroom we often abstract from differences in prices by assuming an economy with a single product and therefore summarize the basic wage determination condition by saying that a competitive firm pays a wage equal to the marginal product of labor. But when we recognize the multiproduct nature of the economy, we say that the competitive firm pays a nominal wage equal to the marginal revenue product of labor, i.e., to the marginal product of labor multiplied by the price of the firm's product. The key real relation must therefore be between changes in productivity in the nonfarm business sector and changes in the nominal compensation paid in that sector deflated by the product price and not by some consumer price that also reflects goods and services produced outside the domestic nonfarm business sector.

What does theory say about the relation between productivity growth and the rise of wages? Labor productivity is defined as the output per hour of labor input, i.e., as the average output per unit of labor. In the special case of Cobb-Douglas technology, the marginal product of labor is proportional to the average product of labor , i.e., to productivity. In that case, the wage paid by a competitive firm should rise at the same rate as the rise in productivity. With a more general technology, however, the marginal product of labor is not necessarily proportional to productivity. For example, if capital deepening causes a rise in productivity and the elasticity of substitution between capital and labor is greater than one, the marginal product of labor will rise proportionately less than productivity. The implication of this is that since the actual technology may not correspond to the Cobb-Douglas specification, we should not be surprised if compensation and 
productivity do not move exactly in proportion to each other.

Whatever the technology, the competitive firm pays a nominal wage equal to the marginal revenue product of labor. As I noted, this implies that the real marginal product of labor should be compared to the wage deflated by the product price and not by some consumer price index. The CPI differs from the nonfarm product price in several ways. The inclusion in the CPI, but not in the nonfarm output price index, of the prices of imports and of the services provided by owner occupied homes is particularly important.

Between 1970 and 2006, the implicit price deflator for the output of the nonfarm business sector rose at an annual rate of 3.8 percent while the consumer price index (the CPI-U series with the research series for the years after 1978) rose at 4.3 percent. If one uses the CPI data to calculate real compensation, its growth is reduced to 1.2 percent a year and therefore substantially less than the 1.9 percent annual rise in productivity. Since the productivity tables in the Economic Report of the President and in Economic Indicators use the CPI to define real compensation, it is not surprising that many analysts have concluded that the official data do not support the theoretical relation between productivity growth and compensation. This is, as I have emphasized, a misreading of the data.

There are of course other questions for which using compensation deflated by the CPI or some other consumer price index is appropriate, including measuring changes in the standard of living of wage earners and in the incentive to supply labor. But the nominal compensation deflated by the CPI is not appropriate for 
evaluating the relation between productivity and compensation.

The second error that some analysts make is to compare productivity growth with wages rather than with total compensation. Because of the rapid growth of health insurance benefits and other fringe benefits, wage and salary payments declined from 89.4 percent of total compensation in 1970 to just 80.9 percent in 2006. As a result, the annual rate of increase in wage and salary payments was 0.3 percent less than the rate of increase in total compensation. ${ }^{2}$.

The practice of focusing on wages and salaries also leads to a mistaken view of how the shares of national income have evolved. A very misleading number the ratio of wages and salaries to GDP - fell from 53 percent in 1970 to 46 percent in 2006, appearing to imply a sharp change in the distribution of income. But here both the numerator and the denominator are conceptually wrong. Factor incomes should be compared to national income rather than to GDP. Total employee compensation as a share of national income was 66 percent of national income in 1970 and 64 percent in 2006. This measure of the labor compensation share has been remarkably stable since the 1970s. It rose from an average of 62 percent in the decade of the 1960s to 66 percent in the decades of the 1970s and 1980s and then declined to 65 percent in the decade of the 1990s where it has again been from 2000 until the most recent quarter.

\footnotetext{
${ }^{2}$ Note that these are figures for the entire economy and not just for the nonfarm business sector. A decomposition of total compensation into the cash payment componenet (wages and salaries) and supplements including fringe benefits is not available for the nonfarm business sector.
} 
Another useful way to examine changes in the compensation share is to focus on the nonfinancial corporate sector (as presented in table B14 of the 2007 Economic Report of the President.) This eliminates some of the very highly compensated individuals in the financial sector. It also avoids the problems raised by separating the capital and labor incomes of sole proprietors . Comparing the compensation paid by the nonfinancial corporations to the net value added of the nonfinancial corporations reinforces the conclusions based on the larger scope of industries. In 1970 compensation was 74 percent of the value added of the nonfinancial corporate sector. In the year 2006, it was 73 percent. The decade averages rose from 70 percent in the 1960s and were very stable after that: 73 percent in the 1970s and 1990s, 74 percent in the 1980s and 75 percent since 2000.

Changes in productivity are not immediately reflected in compensation. The concurrent (i.e., within year) effect of a rise in productivity is a less than a one-forone rise in compensation. More specifically, a regression relating the change in the logarithm of annual nominal compensation in the nonfarm business sector to the change in the logarithm of annual nominal productivity (where nominal productivity is defined as the product of the real productivity level and the nonfarm business implicit price deflator) shows a coefficient of only 0.79 . When this specification is extended to have two lagged annual changes in productivity, the sum of the coefficients rises to 0.94 and is not significantly different from one ( $\mathrm{p}=$ $0.53){ }^{3}$

\footnotetext{
${ }^{3}$ This regression is estimated with the full sample of years for which official productivity data are available, i.e., 1947 through 2006.
} 
The relatively long lags make it difficult to interpret short run movements in productivity and compensation. In particular, when an economy is coming out of a recession productivity and profits both tend to rise more rapidly because labor that had been on the payroll gets used more effectively. The result is that compensation does not rise as rapidly as productivity. The reverse happens when an economy slows, causing productivity to decline or to grow more slowly.

The period since 2000 appears to be a time in which productivity has grown more rapidly than wages. The average rise in real productivity was 2.9 percent while the average rise in real compensation as conventionally measured using the consumer price index averaged just 1.7 percent. This difference of 1.2 percentage points is however very misleading because of the use of the consumer price index. If we instead compare the average rise in nominal productivity (5.4 percent from 2000 through the third quarter of 2007) with the average increase in nominal compensation (5.0 percent), the gap is reduced to 0.4 percent. In real terms, productivity rose 2.9 percent while the corresponding measure of compensation rose 2.5 percent.

This indication that the difference in recent years is small is confirmed by examining the residuals of the period since 2000 in the regression of nominal wage increases on the current and two annual lags of productivity change for the period since 1949. The mean value for those residuals was -0.43 percentage points in the period from 2000 through the third quarter of 2007, the same as the raw difference between productivity growth and compensation growth.. For comparison, the residuals averaged -0.03 percentage points in the $1990 \mathrm{~s},-0.23$ 
percent points in the 1980 s and a positive 0.34 percent in the 70 s and a positive 0.07 percent in the 1960 s.

Although nominal wage increases in recent years lagged slightly behind productivity gains , this may be a natural result of the rapid rise in capacity utilization (from about 75 percent in 2001-02 to nearly 82 percent in 2006-07) or of the capital deepening that occurred during these years. Those explanations deserve further analysis.

In summary, basic theory reminds us that real compensation should be measured using the same price index that is used to calculate productivity. When this is done, the rise in compensation has been very similar to the rise in productivity.

Cambridge, MA

January 2008 